Crowdsourcing to rescue cultural heritage during disasters: A case study of the 1966 Florence Flood

To cite this article:

Kumar, P. (2020). Crowdsourcing to rescue cultural heritage during disasters: A case study of the 1966 Florence Flood. International Journal of Disaster Risk Reduction, 43, 101371. 


\title{
Crowdsourcing to Rescue Cultural Heritage during Disasters: A Case Study of the 1966 Florence Flood
}

\author{
Pakhee Kumar \\ IMT School for Advanced Studies Lucca, Italy - 55100
}

\begin{abstract}
Illustrating the application of crowdsourcing in disaster response before the Internet age, this paper addresses two key questions: How did the people respond to the cultural heritage damaged during the 1966 Florence Flood? How were they motivated to do so? Content analysis of 180 out of 753 correspondence items from the archives of Fondazione Centro Studi Sull'Arte Licia e Carlo Ludovico Ragghianti in Lucca, Italy shows that the committee received contributions in the form of money, materials, volunteers and knowledge from different parts of the world. The most popular of all contributions, however, was money. Four main factors were found to be motivating people to contribute: 1) the call to participate, 2) the media, 3) influencers, and 4) memory of the city. Of key importance, this paper emphasizes: how to initiate a crowdsourcing campaign to restore cultural heritage, who will contribute or is most likely to contribute and how to motivate people to contribute.
\end{abstract}

Keywords: Crowdsourcing; Cultural Heritage; Disaster; Floods; 1966

Florence Flood; Disaster Response

\section{Introduction}

Crowdsourcing is an umbrella term for a variety of approaches [1] in which a large group of people perform small tasks in order to achieve a collective goal.

\footnotetext{
* Corresponding author

Email address: pakhee.kumar@imtlucca.it (Pakhee Kumar)
} 
While researchers argue that crowdsourcing is an Internet phenomenon [2, 3], the practice pre-dates the information age with examples of crowdsourcing evident across history, such as the compilation of the Oxford English Dictionary in 1879 and Mass Observation in 1937 [4]. Since the inception of the term crowdsourcing in 2006 by Jeff Howe [5], the term has been applied to several different domains, including disaster management. The existing research on crowdsourcing in disaster management focuses on online participatory and collaborative work. However, even before the Internet age, geographically dispersed crowds of people worked collaboratively, as evident in the case of the 1966 Florence flood.

The 1966 flood was one of the most catastrophic disasters in terms of damage to the cultural heritage of Florence [6]. A United Nations Educational, Scientific and Cultural Organization (UNESCO) report estimated that thousands of items in libraries, museums, archives and institutions were affected [7]. Many artworks were irretrievably lost or severely damaged. For instance, Cimabue's Crucifix in the Santa Croche lost paint from one-third of its surface [8]. Moreover, many historic buildings were also affected.

The immense loss of cultural heritage stimulated the heritage professionals into immediate action. Carlo Ludovico Ragghianti, a renowned Italian art historian, headed the establishment of Comitato del Fondo Internazionale per Firenze (CFIF, henceforth) in Italy. The committee consisted of erudite members of the art and allied fields 1 It leveraged the capacity of a geographically dispersed crowd of sympathetic people to provide help in any possible form.

1 A few of the committee members include: Professor Roberto Salvini, Ordinary of history of art at the University of Florence; Professor Ugo Procacci, Superintendent of Galleries; Professor Guido Morozzi, Superintendent of Monuments; Professor Gulielmo Meetzke, Superintendent of Etrurian Antiquities; Professor Charles de Tolnay, Director of Buonarroti's House; Alessandro Bonsanti; Mr. Myron Piper Gilmore, Director of Berenson's Villa, from Harvard University; Professor Ulrich Middeldorf, Director of German Institute of History of Art; Professor Emanuele Casamassima, Director of the National Library; Professor Sergio Camerani, Director of the State Archives. 
The committee appealed for contributions towards the restoration of cultural heritage through personal and public communication channels. A letter written by the committee stated:

"The flood in Florence, the 4th of November 1966, has caused more damage to her artistic, cultural, and historic heritage than that done by the war within the walls, in August 1944.

The parliament and government of the nation, the city and all it's (sic) scientific, cultural and artistic groups, are fighting for the immediate salvation of the monuments, works of art, historic archives, and libraries. But the disaster, which has spread through all of Italy, needs just for economic and social measures, many, many hundreds of billions of Lire.

...For centuries Florence has represented the universal spirit of civilization, culture and art in the western world. The testimonies of that historic work, that interests all of the civilized world, must be saved and conserved.

We need everybody.

We send our urgent and painful plea to everyone who wants to give a contribution to the resurrection of Florence, to form an International Foundation destined to recuperate the monuments, documents and artworks.

The contributions, in whatever form they're given, are to be sent to ......'2 2

As a result of this open call, CFIF received contributions in the form of money, materials, volunteers and knowledge from two distinct categories: experts in conservation and restoration, and non-experts. The contributions were received from various parts of the world. Additionally, similar committees were formed in other countries such as the UK, Mexico and the USA; the most notable being the Committee to Rescue Italian Art (CRIA) in the USA, which was under the honorary chairmanship of Jacqueline Kennedy. These committees worked extensively in their respective countries to help restore the cultural heritage of Italy.

\footnotetext{
${ }^{2}$ Alluvione di Firenze 1966 - Comitato Fondo Internazionale per Firenze, Box 1, Fondazione Centro Studi SullArte Licia e Carlo Ludovico Ragghianti, Lucca Italy.
} 
This initiative is an example of crowdsourcing before the Internet age, where the geographically dispersed crowd responded to the disaster according to their capacity. Indeed, the 1966 Florence Flood is probably one of the earliest recorded examples of crowdsourcing during disasters. Concurrently, this event is also considered as a catalyst for disaster preparedness, art conservation and historic preservation [9] by utilizing the international cooperation of experts. But while this initiative remains a major part of the oral history of Italy, no systematic investigation has been done to analyze how people were motivated and how they responded to recover the cultural heritage. This paper will address these gaps through the following questions: How did the people respond to the cultural heritage damaged during the 1966 Florence Flood? How were they motivated to do so?

These questions are particularly important in today's context where the intensity and frequency of disasters affecting cultural heritage have increased [10]. Even though this crowdsourcing initiative occurred before the Internet age, the findings are still relevant today, not only to prepare for disaster response but also to improve the efficiency of crowdsourcing to utilize the power of decentralized collective action. At the same time, this crowdsourcing initiative has also been criticized. Some of Ragghianti's actions in this initiative were denounced [11, 12]. Despite the criticism, there are few parallel examples to date of crowdsourcing in disasters affecting cultural heritage.

This paper is structured in six consecutive parts. Section 2 conceptually frames this research, linking it to existing works on the 1966 Florence Flood, crowdsourcing in disasters and cultural heritage. Section 3 describes the data collection and methodology adopted for this research. Section 4 describes the results. Lastly, Section 5 discusses the implications of this research. The paper concludes with possibilities for future work. 


\section{Related Works}

\subsection{Florence Flood}

A wealth of literature is available on the aftermath of the 1966 Florence Flood. These publications can be broadly divided into two categories: people's narration of the event and experts' reports. Taylor [13] wrote a detailed day-today experience of the flood as a witness of the event. Clark 14] looked back at the flood through the voice of its witnesses. Barrett \& Kraczyna [15] compiled a photographic essay through a selection of eighty-four photographs to represent the event and its aftermath. Pucci \& Paterson [16] provided a brief overview of the floods of the past and illustrated the event through selected photographs. Messeri \& Pintus [17] compiled the stories of volunteers commonly known as Mud Angels. Alexander [18] compared the articles from the Italian and British press to understand the reaction of journalists. He concluded that the Italian press vividly illustrated the dilemmas of the government whereas the British press focused on the art treasures.

The 1966 Florence Flood has also been widely discussed in the field of conservation and historic preservation. Experts reported the damage to books, manuscripts, music manuscripts, archaeological artifacts, etc. They also narrated their personal experiences of the aftermath and elaborated the rescue operations. Phillips [19] mentioned the usefulness of the master plan in the context of archaeological museum recovery. Picker 20] reported the difficulty to accurately determine the extent of damage to libraries and archives in December 1966. He focused specifically on the music manuscripts and books. Hamlin [21] also focused on the damage done to the books and libraries. He provided an early record of rescue efforts by the professionals and volunteers. Bonelli [22] described the process of rehabilitation of the Istituto e Museo di Storia

della Scienza. In contrast, Brommelle [23] provided an overall picture of the restoration works carried out in Florence after the flood. The author described restoration details of stone and marble monuments, sculpture, furniture, woodworks, musical instruments, paintings on wooden panels, paintings on canvas, 
fresco paintings, metallic objects and textiles. Further, he mentioned the establishment of the Restoration Center at Palazzo Davanzati as a permanent consequence of the international aid to Florence after the 1966 flood.

In 2016, the disaster was widely discussed at numerous events and in many publications on the 50th anniversary of the flood. Conway \& Conway [24] provided an overview of the progress in art conservation in the past five decades. However, only a few publications focus on correspondence after this disaster. Waters Rising 9] mainly includes letters between Peter Waters, a pioneering bookbinder, and his wife Sheila Waters, between November 1966 - September 1967. The letters elaborate on the technical and financial challenges faced in handling the mammoth task of restoration and describe the ongoing rescue operations. The letters in this book paint a vivid picture of the event through a family's conversation. Similarly, Dear Eddie and Popp: Letters from the Florence Flood of 66 [25] includes 11 letters from James Hogg (an American artist living in Florence) to his family. The letters were written between November 421, 1966, describing the situation in Florence in detail. Both Waters Rising and Dear Eddie and Popp focus on personal letters sent from one family member to another. In contrast, this paper uses correspondence from various sources around the world. The data, therefore, is not limited to a single person witnessing the disaster, but rather includes various sources contributing from different locations, including those who were not necessarily witnesses to the event.

\subsection{Crowdsourcing in Disasters and Cultural Heritage}

Currently, crowdsourcing has gained tremendous attention to increase the efficiency of response in disaster management. Researchers have developed theoretical frameworks, analyzed case studies and also developed new systems for crowdsourcing. Liu [26] developed a conceptual crisis crowdsourcing framework that establishes the 'why, who, what, when, where, and how' of a crowdsourcing system. Authors have studied numerous crowdsourcing applications available for disaster management in order to understand the role of volunteers and improve the efficiency of the process. For instance, Poblet et al. [27] reviewed 
online platforms and mobile apps developed and implemented in the context of disaster management. The study concluded that the majority of the reviewed platforms and apps focus on the response and recovery phase of disasters. Further, the authors developed four types of crowdsourcing roles based on the type of participation and data processing, including crowd as a sensor, crowd as a social computer, crowd as a reporter, and crowd as a microtasker. Ernst et al. 28] focused on location-based tasks carried out by volunteers using three core processes: sensing, awareness and adaptability. By studying various mobile-based crowdsourcing applications, the authors suggested that these approaches can help emergency managers to not only gather information but also make accurate decisions. Further, Gao et al. [29] highlighted the main causes behind a shortfall of crowdsourcing for disaster relief coordination, such as limitations of crowdsourcing applications and the kind of data posted on them. The authors introduce the concept of 'groupsourcing' for efficient coordination between different relief organizations. Kankanamge et al. [30 concluded that in spite of the wide application of crowdsourcing in disaster management, it is considered a 'random tool', particularly by emergency managers. Further, they highlighted the lack of an agreed-upon definition and application of crowdsourcing in disaster management. The authors carried out a systematic literature review and established four key attributes of crowdsourcing: location awareness, multi-directional communication, situation awareness, and collective intelligence. These key attributes indeed point to the usability of crowdsourcing in disaster management.

Significant progress has been made in the application of crowdsourcing for humanitarian purposes during disasters, by utilizing online crowdmapping applications. For instance, after the 2010 Haiti earthquake, thousands of volunteers around the world collaborated on the Internet to provide aid to the response organizations on the ground using Ushahidi, an online mapping platform[31]. Similarly, volunteers have also contributed to online crowdmapping applications using satellite imagery. For instance, during the 2013 Typhoon Haiyan in the Philippines, 1,679 contributions were made to the OpenStreetMap (OSM), an 
online crowdmapping tool, from 82 countries 32. Similar trends have been seen in many disasters across the world, such as the 2011 Queensland floods in Australia, the 2011 Christchurch earthquake in New Zealand, the 2011 tsunami in Japan [33, the 2015 Nepal earthquake [34, and so on. Over the last decade, online crowdmapping repeatedly proved its potential and usefulness in disaster management [35, 36].

Additionally, new crowdsourcing systems have also been developed for increasing efficiency in disaster response in the form of mapping and classification. Researchers have attempted to utilize the skills and expertise of off-site volunteers to provide support to on-site users. For instance, Yang et al. [37] developed a crowdsourcing disaster support platform by utilizing off-site users. In their platform, they focus on three distinct attributes: the selection of off-site users according to their expertise, mechanisms for off-site users to collaborate and crowd-voting for increasing credibility of the information. Researchers have combined machine learning and crowd participation to improve the crowdsourcing process in disaster management. Artificial Intelligence for Disaster Response (AIDR), developed by Imran et al. [38, automatically classifies tweets related to a disaster, using human intelligence to label a sample of tweets in order to train the automatic classifier. Lin et al. [39] developed the Artificial and Crowd Intelligence filter to improve the crowd response accuracy. In their system, artificial intelligence is used to segregate accurate messages from inaccurate ones. Further, the crowd combines the duplicates, removes inaccurate messages and formats the messages.

In comparison, a limited application of crowdsourcing has been done in the context of cultural heritage during disasters. An attempt to harness the power of digital volunteers was done during the earthquake in Nepal in 2015 through a crowdsourcing application: 'Kathmandu Cultural Emergency Crowdmap' 40]. A similar effort was initiated by Wikipedia after the fire in the National $\mathrm{Mu}-$ seum of Brazil in 2018 [41]. Both Kathmandu Cultural Emergency Crowdmap and Wikipedia sought information from the crowd after the disaster. While Kathmandu Cultural Emergency Crowdmap sought information for rapid dam- 
age assessment to cultural heritage, Wikipedia sought information to preserve the memory of cultural heritage. Overall, the current research and application of crowdsourcing in the disaster management domain generally refer to a large group of people participating and collaborating via the Internet. In contrast, this paper shows that crowdsourcing during disasters is not a new practice and is not limited to digital volunteers.

Despite the challenges highlighted by Oomen \& Aroyo [42] due to a variety of reasons (such as data quality and motivating the crowd), crowdsourcing has also been widely applied in the cultural heritage domain. Libraries and archives invite users to transcribe and/or correct the outputs of the digitization process. New York Public Library's project What's on the Menu [43, University College London's Transcribe Bentham [44, and National Library of Australia's Trove [45] are a few examples of crowdsourcing for transcription of archives. Know Your Place [46] and Library of Congress's Flicker The Commons [47] gather descriptive metadata related to objects in a collection. 9/11 Memorial \& Museum's Make History [48, Brooklyn Museum's projects Click and Go [49], and University of Sussex's Mass Observation [4, 50] used the inspiration and expertise of non-professional curators to create (Web)exhibits. In the context of crowdsourcing in cultural heritage, researchers [51] prefer the notion of 'community' over the 'crowd' as a conceptual model, because most of these projects depend on a dedicated community of volunteers instead of large numbers of volunteers. In contrast, a large crowd of volunteers, both on-site and off-site, contributed to rescuing the cultural heritage after the 1966 Florence Flood. Moreover, the current research into crowdsourcing in cultural heritage also focuses on participatory online practices.

The main difference between crowdsourcing in the pre-Internet age and the present times is the medium of communication used. As also evident from other crowdsourcing initiatives before the Internet age, crowdsourcing relied heavily on the manual labor of the crowd. For instance, in 1937, volunteers manually maintained a diary in order to record their daily observations in the Mass Observation project. Volunteers also sent excerpts of word usage in literary works on 
scraps of paper to compile the Oxford English Dictionary in the 1870s [4, 52. As a result, only the crowdsourcer could view and analyze the submissions. Even though the crowd worked independently towards a common goal before the Internet age, the process of crowdsourcing tended to be strictly top-down. Moreover, the crowdsourcing projects operated for years. For instance, the Oxford English Dictionary took approximately 70 years to complete [52]. Today, the Internet affords instantaneous information creation, dissemination and circulation. Further, various applications ease data collection and processing of large amounts of data available through the Internet. As a result, crowdsourcing initiatives in the present time can instantly utilize a large amount of globally-spread people for disaster response. Moreover, the Internet has also changed the crowdsourcer-crowd relationship from strictly 'top-down' to more diverse relationships including lateral, bottom-up and top-down [53]. While the medium has also had an impact on dissemination patterns, techniques and outreach, this research's findings are applicable for crowdsourcing initiatives even in present times, as will be discussed in the forthcoming sections of this paper.

\section{Material and Methods}

\subsection{Material}

In conducting this research, I used the 1966 Florence Flood archives of Fondazione Centro Studi Sull'Arte Licia e Carlo Ludovico Ragghianti in Lucca, Italy as the primary source of information. The archives contain committee reports and correspondence with the committee. The list of documents in the archive is available online on the foundation's website http://www.fondazioneragghianti.it. In this paper, I focus on the correspondence with the committee. Analysis of correspondence is an obvious choice to answer the research questions guiding this paper for three reasons. Firstly, the correspondence items are from various parts of the world and truly represent the extent of the committee's outreach. Secondly, many respondents explicitly mention their motivation for contribution. Lastly, the correspondence is not limited to those employed in the art 
world and includes the responses from a wider section of the global society.

Hence, the correspondence provides an in-depth understanding of the process of crowdsourcing.

The correspondence is stored in 11 boxes sorted based on the respondents last name. A total of 753 unique sources of correspondence have been identified. Additionally, a few items of correspondence from unidentified sources are also available in the archive. In many cases, one source wrote multiple letters and telegrams. However, the average number of items of correspondence per donor is 1.3 ; that is, most sources only corresponded once. The correspondence items are mainly from the sources to CFIF and very few of those sent from CFIF are available in this archive. Moreover, many sources sent attachments with the correspondence. Such attachments included bank drafts, bank checks, newspaper articles, magazine articles, photographs and biographical information describing the prominent people of a country. Section 4.1 provides an overall view of the 753 correspondence items. A sample of 24 correspondence items are provided in Appendix A

\subsection{Method}

The methodology adopted for this paper is comprised of eight distinct steps, as explained in Figure 1. The 753 unique sources of correspondence mentioned above were tabulated in an Excel sheet in alphabetical order. Additional information such as date of correspondence, type of source, location, language and means of communication for each source was manually added. Section 4.1 describes the results of this annotation. Data on five sources was not available. Nevertheless, these sources were kept on the list. 


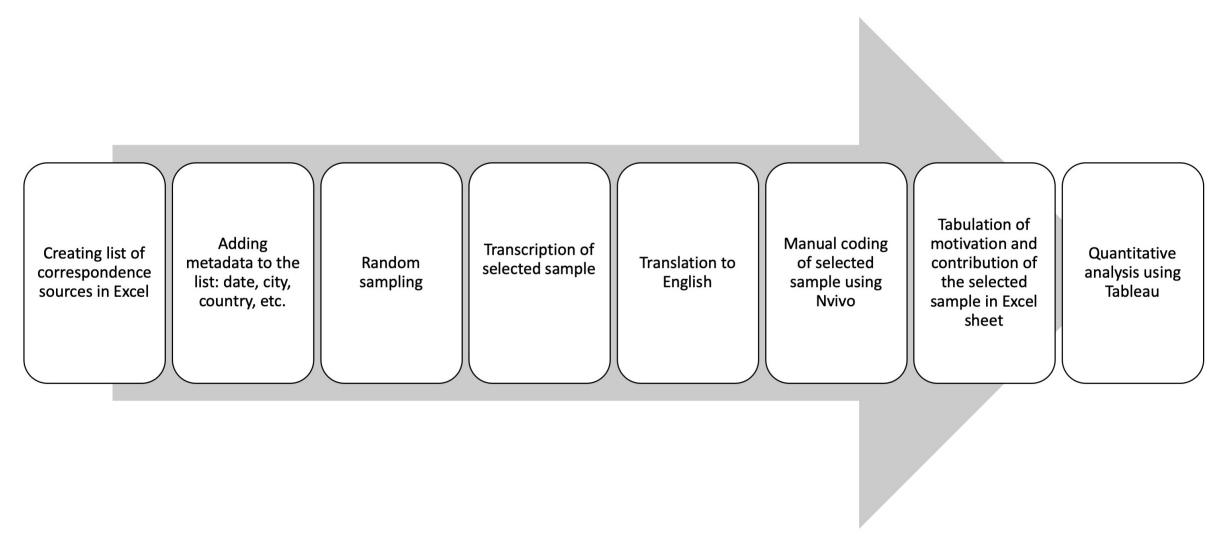

Figure 1: Overview of Methodology

A random sampling method was selected in order to avoid any bias in the selection. The random sample was created using the Excel sheet containing metadata on the source of correspondence. A total of 180 out of 753 sources were selected for analysis, i.e. about $24 \%$ of the correspondence. In many cases, one source had multiple correspondence items. In such cases, all the correspondence items were selected for analysis. Moreover, the correspondence attachments were also studied to understand the contextual information. The selected sample is diverse. It includes correspondence from Italian and nonItalian individuals, public and private bodies from Italy and abroad; and a combination of telegrams, typed letters and handwritten letters.

Correspondence items from the selected sources were first transcribed in Nvivo, a qualitative data analysis software. It should be noted that handwritten letters were particularly difficult to transcribe. In some cases, a few words were undecipherable and, therefore, not transcribed. However, this did not compromise the understanding of the overall message of the correspondence. The transcribed correspondence items were translated to English with the help of native speakers. Google translator was also used to aid the understanding of correspondence. Translation to English was an essential step in harmonization of the analysis. Manual content analysis of the selected sample was done to understand the thematic patterns of response and construct underlying meanings. 
As Krippendorff and Weber suggest, content analysis includes analysis beyond the literal message itself [54, [55]. This paper briefly touches on the correspondents' location, language and means of communication, and their role in society, to understand the context. Lastly, the type of contribution and the motivation for contribution for the 180 selected sources were tabulated in the Excel sheet. Data was quantitatively analyzed using Tableau, a quantitative data analysis software.

To understand communications, it is also important to understand the technological context of 1966 . While the first supercomputer was already built and research on networking was ongoing, such technologies were still not available to the masses. People relied on letters, telephones and telegrams for personal communication; and TV, radio, newspapers for mass communication. This is reflected in the nature of the correspondence which includes handwritten letters, postcards, greeting cards, visiting cards, typewritten letters on personal letterheads or institutional letterheads and telegrams. This is also reflected in the content of letters and telegrams. The telegrams tend to be short, and to-thepoint as it was an expensive means, whereas the letters give more flexibility to the correspondent and range from just a few words to long letters of 2-3 pages.

It is also important to elaborate on the specific language type used in telegrams. Sending telegrams was expensive and, therefore, people aimed to provide as much information in the smallest possible number of words. Hence, some of the words were abbreviated, omitted or added for a specific purpose. For instance, the term stop in a telegram refers to the end of a sentence, as elaborated in the telegram "WILL CERTAINLY SEND DONATION STOP CONTACTING BRITISH ITALIAN SOCIETY LONDON STOP DEEPEST SYMPATHY YOUR TERRIBLE DISASTER'3. In the absence of this knowledge about specific language usage in telegrams, one might risk a wrong analysis of correspondence.

\footnotetext{
${ }^{3}$ Alluvione di Firenze 1966 - Comitato Fondo Internazionale per Firenze, Box 4, Fondazione Centro Studi SullArte Licia e Carlo Ludovico Ragghianti, Lucca Italy.
} 


\section{Results}

The results are divided into three main parts. Section 4.1 describes the generic results of data annotation. It provides an overall view of the 753 correspondence items, whereas Sections 4.2 and 4.3 refer to the 180 randomly selected correspondence items. Sections 4.2 and 4.3 answer the primary research questions in this paper. A sample of 24items of correspondence is provided in Appendix A. These correspondence samples are frequently referred to in Sections 4.2 and 4.3 .

\subsection{General Observations}

The 753 unique sources of correspondence can be divided into 20 categories (Refer to Table 1), based on the role of the source as a respondent. The table also highlights the location of sources, the number of sources from each country and the total number of correspondence items from sources. There are a total of 1,019 items of correspondence from 753 sources in this dataset. From Table 1. it is clear that individuals, institutes, universities and schools communicated the most with the committee. Moreover, Table 1 and Appendix A are useful in defining the 'crowd' for this paper as a large number of people and organizations who did not necessarily know each other [3]. The crowd was also heterogeneous in composition [56], including Italian and non-Italian individuals, and public and private bodies from Italy and abroad. Moreover, the crowd was a combination of both non-professionals (e.g. children, students, school teachers, young graduates) and professionals, and organizations in heritage, arts and allied fields, as evident from Table 1 and various correspondence items in Appendix A.

Figure 2 shows that most of the correspondence was written from Italy and the USA. Interestingly, the correspondence is in many different languages such as Italian, English, French, German and Portuguese. Table 3 shows that the most of the correspondence is in Italian (64\%), followed by English (29.6\%),

French, German, Spanish, etc. Table 2 shows the distribution of correspondence with regard to means and type of correspondence. Data on five sources was not 
available, as highlighted in Section 3. From Table 2 it is clear that letters are the dominant means of communication in this dataset. However, some sources sent both letters and telegrams to CFIF. Moreover, people preferred to send typewritten communication over handwritten letters, as evident in Table 2 .

Lastly, the correspondence was written between November 1966 - October 1967. Figure 3 shows that most of the correspondence was written in NovemberDecember 1966. The intensity of incoming correspondence decreased with time. On average, seven items of correspondence were sent/received per day between November 1966 - December 1967. While the restoration of cultural heritage was ongoing even after 1967, this correspondence is limited in the time frame. Nevertheless, it provides an in-depth understanding of people's response.

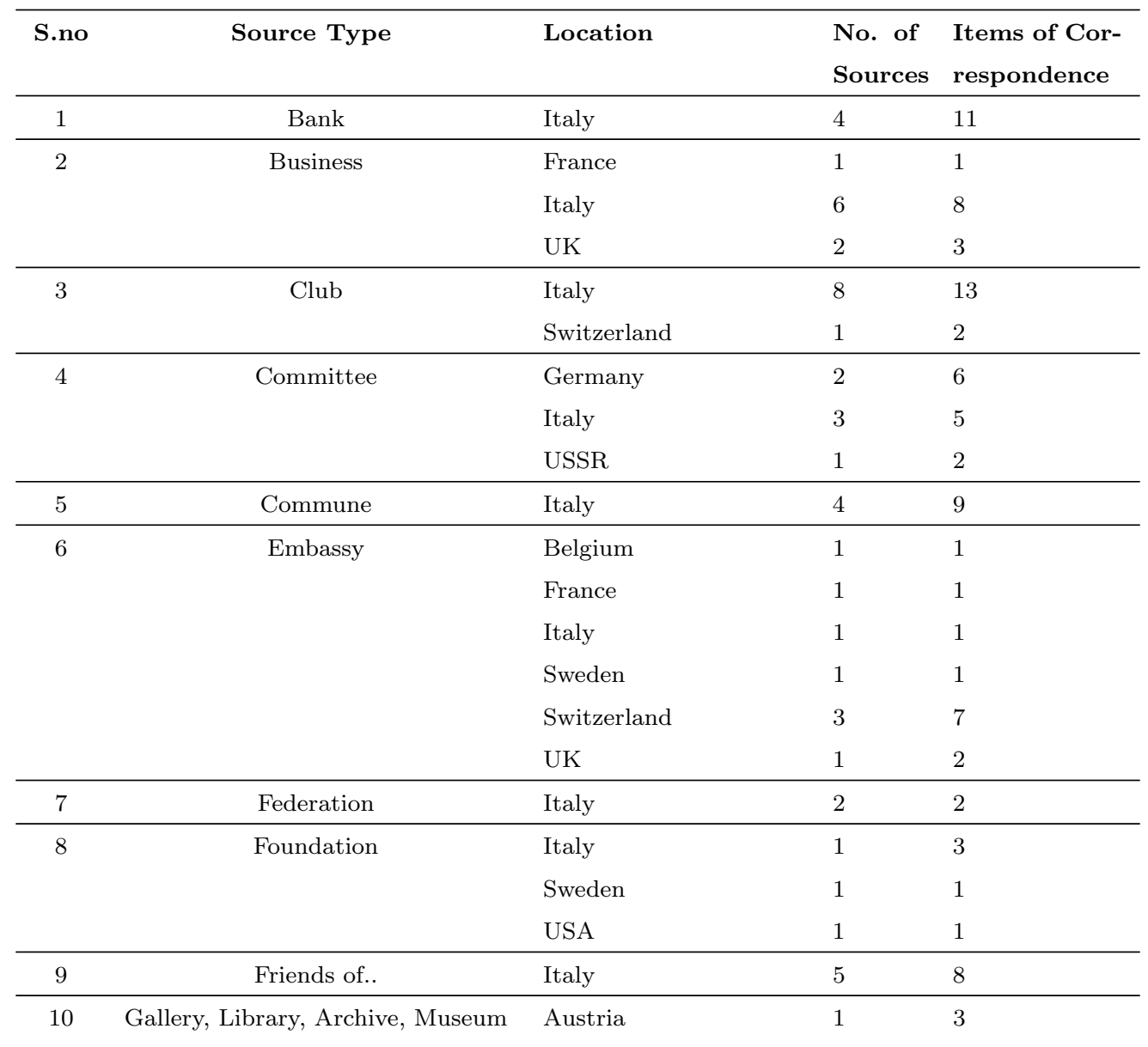




\begin{tabular}{|c|c|c|c|c|}
\hline & & Canada & 1 & 1 \\
\hline & & Denmark & 1 & 1 \\
\hline & & Germany & 3 & 3 \\
\hline & & Ireland & 1 & 3 \\
\hline & & Italy & 3 & 7 \\
\hline & & Netherlands & 1 & 1 \\
\hline & & Norway & 1 & 1 \\
\hline & & Spain & 1 & 1 \\
\hline & & Switzerland & 2 & 4 \\
\hline & & UK & 1 & 2 \\
\hline & & USA & 2 & 2 \\
\hline \multirow[t]{18}{*}{11} & Individuals & Argentina & 1 & 2 \\
\hline & & Austria & 1 & 1 \\
\hline & & Belgium & 2 & 3 \\
\hline & & Brazil & 1 & 1 \\
\hline & & Canada & 1 & 1 \\
\hline & & Croatia & 1 & 1 \\
\hline & & Denmark & 1 & 1 \\
\hline & & France & 16 & 30 \\
\hline & & Germany & 14 & 15 \\
\hline & & Italy & 266 & 322 \\
\hline & & Malta & 1 & 1 \\
\hline & & New Zealand & 1 & 1 \\
\hline & & Spain & 1 & 1 \\
\hline & & Sweden & 2 & 2 \\
\hline & & Switzerland & 5 & 6 \\
\hline & & Undefined & 39 & 39 \\
\hline & & UK & 7 & 7 \\
\hline & & USA & 207 & 214 \\
\hline \multirow[t]{9}{*}{12} & Institutes & Argentina & 1 & 1 \\
\hline & & Belgium & 1 & 3 \\
\hline & & Brazil & 3 & 14 \\
\hline & & France & 4 & 8 \\
\hline & & Germany & 1 & 2 \\
\hline & & Italy & 36 & 63 \\
\hline & & Mexico & 2 & 2 \\
\hline & & New Zealand & 1 & 4 \\
\hline & & Poland & 1 & 1 \\
\hline
\end{tabular}




\begin{tabular}{|c|c|c|c|c|}
\hline & & Portugal & 1 & 1 \\
\hline & & Spain & 2 & 2 \\
\hline & & Sweden & 2 & 5 \\
\hline & & Switzerland & 4 & 6 \\
\hline & & UK & 1 & 1 \\
\hline & & USA & 1 & 1 \\
\hline 13 & Ministry & Italy & 1 & 9 \\
\hline \multirow[t]{2}{*}{14} & Newspaper/Magazine & Italy & 6 & 10 \\
\hline & & UK & 1 & 1 \\
\hline 15 & Political Party & Italy & 1 & 1 \\
\hline \multirow[t]{3}{*}{16} & Society & Germany & 2 & 3 \\
\hline & & Italy & 3 & 11 \\
\hline & & Uruguay & 1 & 4 \\
\hline \multirow[t]{3}{*}{17} & Theater & Italy & 2 & 2 \\
\hline & & Sweden & 1 & 1 \\
\hline & & UK & 1 & 2 \\
\hline \multirow[t]{2}{*}{18} & Trade Union & Italy & 1 & 1 \\
\hline & & USA & 1 & 1 \\
\hline 19 & TV/Radio & Belgium & 1 & 2 \\
\hline \multirow[t]{7}{*}{20} & University or School & Belgium & 1 & 3 \\
\hline & & Brazil & 1 & 1 \\
\hline & & Germany & 2 & 3 \\
\hline & & Italy & 23 & 50 \\
\hline & & Sweden & 1 & 1 \\
\hline & & UK & 1 & 2 \\
\hline & & USA & 6 & 32 \\
\hline & Total & & 753 & 1,019 \\
\hline
\end{tabular}

Table 1: The sources were categorized in 20 classes according to the role of the source. The table highlights the location of each source type, number of sources and total number of items of correspondence.

Many of the correspondence items are replies to the communication sent by CFIF. On the other hand, some are self-initiated. Different levels of formality can be seen in the letters. Some of the letters have a personal tone, whereas some have a formal tone. This represents the different relationship levels members of CFIF had with the correspondents. 


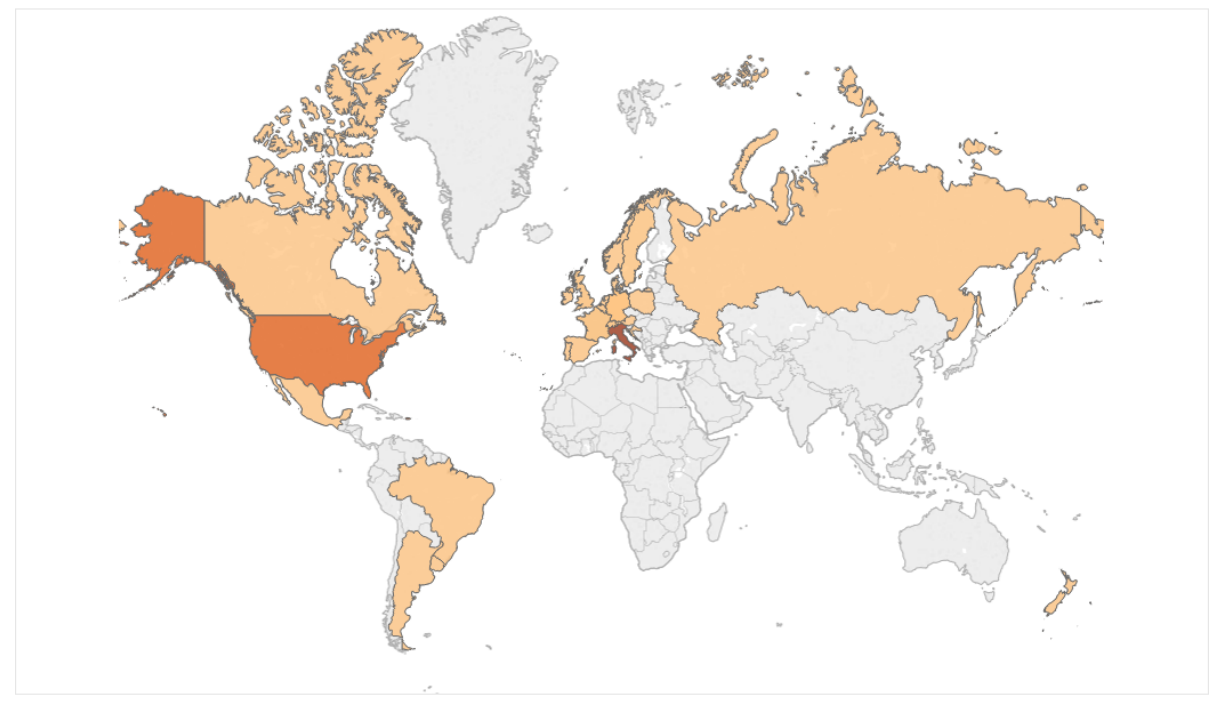

Number of Records

376

Figure 2: Contributions from 25 countries were received. Most contributions were received from Italy and the USA.

\begin{tabular}{|c|c|c|}
\hline \multicolumn{2}{|c|}{ Means of Communication } & No. of Correspondence Items \\
\hline \multicolumn{2}{|l|}{ Letters } & 689 \\
\hline \multicolumn{2}{|l|}{ Telegrams } & 48 \\
\hline \multicolumn{2}{|l|}{ Letter + Telegram } & 11 \\
\hline Unknown & & 5 \\
\hline Total & & 753 \\
\hline Type & No. & of Correspondence Items \\
\hline Typewritten & 421 & \\
\hline Handwritten & 321 & \\
\hline Hand + Type & 6 & \\
\hline Unknown & 5 & \\
\hline Total & 753 & \\
\hline
\end{tabular}

Table 2: Most of the correspondence items were letters and typewritten.

\subsection{How did the people respond?}

Three main themes emerged from the analysis- action, memory and sentiment. The items of correspondence which elaborated any form of contribution or willingness to contribute were coded under the theme of 'action'. Correspondence items which described sources' past experience(s) in Florence were coded 


\begin{tabular}{ll} 
Language & No. of Correspondence Items \\
\hline Italian & 482 \\
English & 223 \\
French & 16 \\
German & 14 \\
Spanish & 6 \\
Multilingual & 5 \\
Unknown & 5 \\
Portuguese & 1 \\
Maltese & 1 \\
\hline Total & $\mathbf{7 5 3}$
\end{tabular}

Table 3: The correspondence was written in seven different languages. Some correspondence was multilingual.

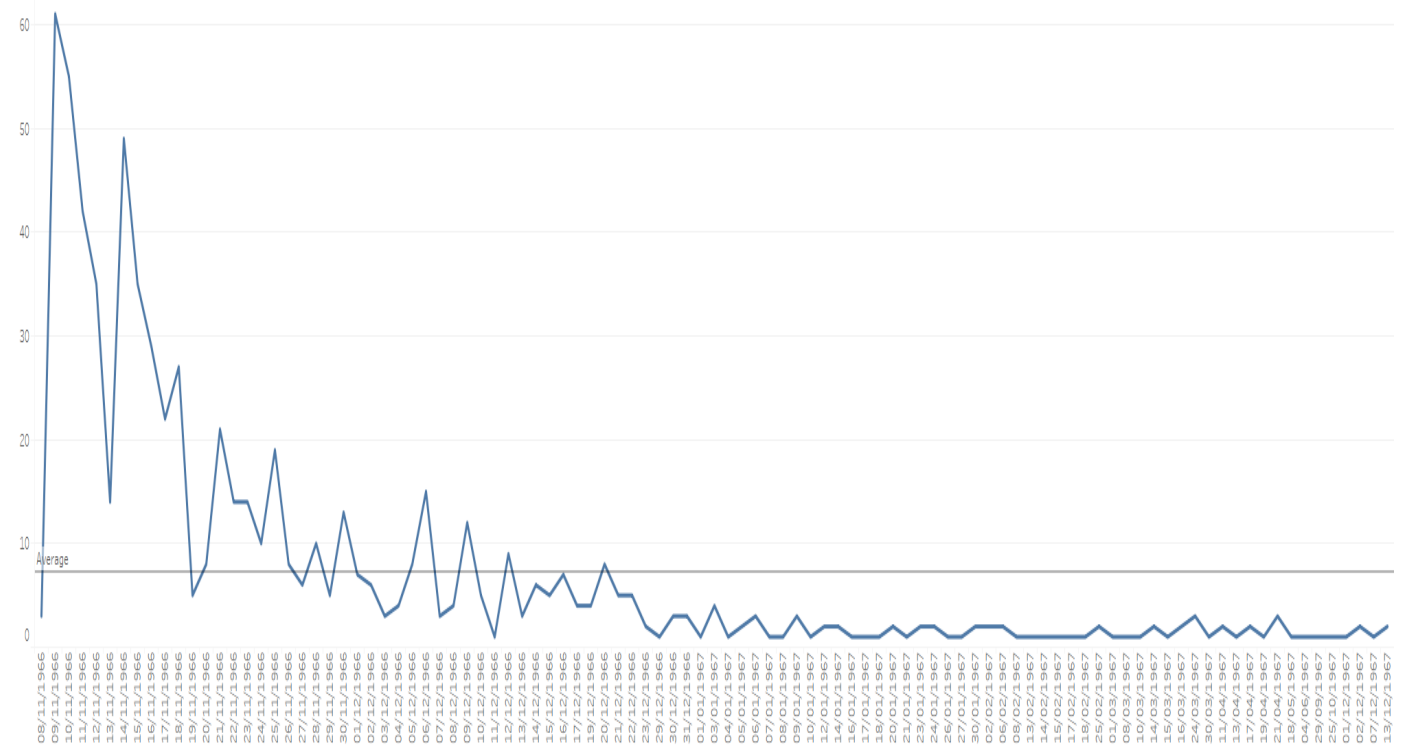

Figure 3: The intensity of correspondence decreased with time. On average, seven items of correspondence were sent/received per day. 
under the theme 'memory'. Lastly, correspondence items which expressed any sentiment over the loss of heritage were coded under the theme 'sentiment'. It should be noted that the themes were not necessarily mutually exclusive. Some examples of coding can be seen below:

1. Action Please accept this small contribution towards the fund for helping the city of Florence

2. Action + Memory Here is my little contribution to your fund for the restoration of the art treasures of your wonderful city which I enjoyed greatly two years ago. I read in the New York Times of Nov 9th that such gifts could be addressed to you for the committee 5

3. Action + Sentiment Mr. Days and I adore Italy-and particularly, Florence. We're so upset about your disaster. Am enclosing check- only wish it could be for a much greater sum ${ }^{6}$

4. Action + Memory + Sentiment In 1925 I was in Florence 12 days and these few days have given me a new idea of art. For me, not only this door of the Baptistery, but every stone in Florence, every fresco, every painting, was almost a door to paradise. This tragedy of Florence is something entirely personal. Please accept this small sum of twenty dollars .... excuse my poor use of the beautiful language 7

Most of the correspondence refers to some sort of action; either immediate or a promise of future action. In some correspondence, action taken is not evident but implied. Since the telegrams tend to be short, very few telegrams express sentiment and none of them describes past experience in Florence. On the other

\footnotetext{
${ }^{4}$ Alluvione di Firenze 1966 - Comitato Fondo Internazionale per Firenze, Box 2, Fondazione Centro Studi SullArte Licia e Carlo Ludovico Ragghianti, Lucca Italy.

${ }^{5}$ Alluvione di Firenze 1966 - Comitato Fondo Internazionale per Firenze, Box 9, Fondazione Centro Studi SullArte Licia e Carlo Ludovico Ragghianti, Lucca Italy.

${ }^{6}$ Alluvione di Firenze 1966 - Comitato Fondo Internazionale per Firenze, Box 5, Fondazione Centro Studi SullArte Licia e Carlo Ludovico Ragghianti, Lucca Italy.

${ }^{7}$ Alluvione di Firenze 1966 - Comitato Fondo Internazionale per Firenze, Box 5, Fondazione Centro Studi SullArte Licia e Carlo Ludovico Ragghianti, Lucca Italy.
} 


\begin{tabular}{lll} 
Contribution Type & No. & $\mathbf{\%}$ \\
\hline Money & 145 & $80.5 \%$ \\
Promise to Contribute & 14 & $7.7 \%$ \\
Volunteer & 6 & $3.3 \%$ \\
Knowledge & 4 & $2.4 \%$ \\
Money+ Volunteer & 3 & $1.7 \%$ \\
Unable to Contribute & 3 & $1.7 \%$ \\
Material & 2 & $1.1 \%$ \\
Money+Material & 2 & $1.1 \%$ \\
Material+ Volunteer & 1 & $0.5 \%$ \\
\hline Total & $\mathbf{1 8 0}$ & $\mathbf{1 0 0 \%}$
\end{tabular}

Table 4: Distribution of the type of contributions. The most popular amongst all was the contribution of money.

hand, the letters were found to be a hybrid of themes in that they not only focused on action but also expressed sentiments and/or shared memories. None of the letters only shared a memory or expressed sentiment. Action was certainly the prime objective of this correspondence. In letters, the three themes were found to be closely related, particularly in the communication of the international respondents. People who had visited Florence whether as a tourist, student or professional vividly remembered their time in Florence, expressed sadness about the loss of heritage and contributed towards response according to their own capacity.

As evident from the correspondence, contributions came in four specific forms: money, materials, volunteers and knowledge. Table 4 highlights that most sources contributed money (80.5\%), followed by volunteers (3.3\%), knowledge $(2.2 \%)$ and material (1\%). Moreover, Table 4 also highlights that some correspondents $(7.7 \%)$ promised to contribute at a later date. A few correspondence also mentioned the inability to contribute (1.7\%). Lastly, Table 4 highlights that a few sources (3.3\%) sent multiple forms of contributions. Appendix A provides examples of correspondence and attachments.

\subsubsection{Contribution of Money}

The most popular contribution was money, as evident from Table 4 People contributed according to what they could afford, as expressed in many letters. 
Some of the letters explicitly mention the amount contributed whereas others mention 'a small contribution' instead of the actual amount. From the data available, individuals contributed from 5 USD to 10,000 USD in a personal capacity. Interestingly, the contribution of money also came from children (refer to 17 in Appendix A). The organizations had the capacity to contribute more (800 USD - 1,600 USD) and many organizations kept sending contributions at regular intervals. References 1, 2, 4, 5, 6, 12, 13, 14, 17, 19, 22 and 23 in Appendix A are examples of correspondence which show the contribution of money. Example 11 mention that the goal of the American committee was to raise $\$ 3.2$ million.

Fundraising through Events. Some letters highlight the fundraising campaign through events such as lectures, conferences, musical recitals, exhibitions and lotteries (see 13, 14, 15 in Appendix A). Such events happened in both Italy and abroad. The contributions received were not only through art events organized by large scale organizations, but also through other, smaller events. Example 17 shows the organization of a cookie and candy sale by children to raise money for the restoration.

\subsubsection{Contribution as Volunteers}

Students had a crucial role in the restoration of cultural heritage after the flood. Cultural institutions sent art student volunteers with professional restorers to carry out the restoration work. Some art students volunteered help in the rescue work by covering their own expenses, whereas others showed an inclination to volunteer if any opportunity was available (refer to 3 and $21 \mathrm{in} \mathrm{Ap}-$ pendix A). However, the interest in volunteering to rescue cultural heritage was not limited to the people in art and allied fields. The correspondence highlights

other professionals, such as doctors, who were willing to work as volunteers to restore the cultural heritage of Florence. Table 4 highlights that six sources in the selected sample expressed a willingness to volunteer, three sources sent money and volunteers, and one source donated materials and volunteers. 


\subsubsection{Contribution of Knowledge}

The field of conservation was still evolving in 1966. As a result, knowledge was also exchanged through letters on conservation techniques. Howard E. Gruber from Rutgers University suggested a technique based on his own experience of salvaging several hundred books (refer to example 16 in Appendix A). As seen in Table 4, four out of 180 sources contributed knowledge to rescue cultural heritage affected by the floods.

\subsubsection{Contribution of Materials}

The contribution also came in the form of materials (see example 20 in Appendix A . Materials donated ranged from paintings to cleaning equipment and air heaters for efficient drying of artworks. While some sources donated single items, a few donated a large number of materials. Most such donations came from large scale organizations like businesses and universities. Table 4 shows that two sources contributed materials, two sources donated materials with money, and one source donated materials and volunteers to rescue cultural heritage.

\subsubsection{A Promise to Contribute}

Fourteen out of 180 correspondence items highlight a promise to contribute at a later date. These correspondence items explicitly mention the ongoing (collection) efforts. Examples 8 and 9 in Appendix A correspondence show the ongoing efforts in Canada and the USA. These letters do not mention any contribution being sent with the correspondence; however, they exemplify that the bigger organizations worked in a formal way.

\subsubsection{Unable to Contribute}

Three out of 180 correspondence explicitly mentioned their inability to contribute due to a variety of reasons. Firstly, the mandate of a few contacted institutions barred them from contributing (see 18 in Appendix A. Secondly, the letters elaborate that some sources received requests from different committees working towards the same cause. Obviously, the sources could not contribute to 
multiple committees. Lastly, those who could not contribute financially found other ways to contribute. For instance, example 10 in Appendix A was written by an individual who was not able to contribute financially.

\subsection{How were people motivated?}

The analysis highlights four main factors in motivating people: 1) the call to participate, 2) media, 3) influencers, and 4) memory. However, several correspondence items $(37 \%)$ in the selected sample did not explicitly mention their motivation for contributing, as evident from Table 5 Memory was found to be the greatest motivation behind contributions, followed by the call to participate, media and influencer. Table 5 further highlights that these factors also worked in combination.

\begin{tabular}{lll} 
Motivating Factor & No. & $\mathbf{\%}$ \\
\hline Not Mentioned & 67 & $37.2 \%$ \\
Memory & 32 & $17.7 \%$ \\
Call to Participate & 29 & $16.2 \%$ \\
Media & 20 & $11.2 \%$ \\
Media + Influencer & 12 & $6.7 \%$ \\
Media + Memory & 11 & $6.2 \%$ \\
Influencer & 7 & $3.8 \%$ \\
Influencer + Memory & 1 & $0.5 \%$ \\
Media + Call to Participate & 1 & $0.5 \%$ \\
\hline Total & $\mathbf{1 8 0}$ & $\mathbf{1 0 0 \%}$
\end{tabular}

Table 5: Distribution of the motivating factors. Most of the correspondence did not mention the motivation for sending a contribution.

\subsubsection{Role of Memory}

The greatest motivation for people to contribute was their having visited Florence in the past. In this, memory played an important role in people's perception of the need for action (see 2, 4, 5, 7, 12, and 17 in Appendix A).

\subsubsection{The Call to Participate}

The call to participate, initiated by CFIF, is essentially what attracted people initially and motivated them to participate in the initiative. The call to participate was rigorous. The committee personally sent cables and letters to 
many sources, as evident from correspondence 6 and 9 in Appendix A Section 1 provides an example of a letter written by CFIF. This personal call to participate meticulously utilized the already existing network of possible respondents. Such letters have a personal tone, often addressing committee members as friends. Some of the sources were contacted more than once and by different members of CFIF. Moreover, the committee did not hesitate to contact sources whose mandate was outside cultural heritage (refer to 18 in Appendix A. While the telegrams sent by CFIF are not stored in the archive, some drafts of letters are available. The letter in section 1 elaborates that the call for aid gave a sense of urgency. The call compared the 1966 flood to previous disasters, such as the 1944 war and flood of 1277. Moreover, a short notice on university and office notice-boards was also helpful in motivating people to participate (refer to 11 in Appendix A.

\subsubsection{Role of the Media}

The news media played a crucial role in organizing the response, as evident from Table 5. People were motivated to contribute through media such as newspapers, magazines, television and radio. This appeal to masses through media was done in various countries. Example 24 in Appendix A is a newspaper article published on 30 November 1966 in Wellington, New Zealand. Example 23 illustrates that images printed were useful in evoking emotions, thereby motivating individuals to send a contribution. Examples 1, 7 and 22 in Appendix A show that people sent contributions to CFIF after reading a news article in their local newspapers. Moreover, people also showed a willingness to work as volunteers after reading newspaper articles (refer to 21 in Appendix A). On the other hand, some magazines targeted niche interest-groups in appealing for assistance.

\subsubsection{Role of Influencers}

Some of the sources were influential people at the time. Philanthropists, art collectors, professors, writers, journalists and political figures contributed generously to the initiative. Prominent figures like Jacqueline Kennedy (see 9 
in Appendix A and Sir Ashley Clarke chaired similar committees in the USA and UK, respectively. The correspondence highlights that an influencer need not be a prominent figure in society but can be a teacher, parent, friend or colleague (refer to examples 12 and 17 in Appendix A). As evident from Table 5 , seven sources were solely motivated by an influencer. The table also illustrates that 13 sources were motivated by media and memory, in addition to an influencer.

\section{Discussion}

Three main themes emerged from the analysis- action, memory and sentiment. In letters, the three themes were found to be closely related, particularly in the internationals' response. On the other hand, telegrams were short and focused only on action. Whether these themes will still be present in people's response to disasters affecting cultural heritage during the Internet age is a question that requires further research. Indeed, the technological context of 1966 was different from the present times. With participatory technologies such as Twitter, people are able to instantaneously post about disasters. The overall trend of Figure 3 may remain the same in the present times, i.e. the interest in the event is shown to diminish with time. However, the number of respondents may increase significantly due to the availability of the Internet. Moreover, the delay of five days in the response of people visible in Figure 3 is almost incomprehensible in today's context, particularly for a connected city such as Florence.

Money, materials, volunteers and knowledge were the contributions of the crowd. The most popular contribution was money. While this research did not aim to analyse how much money was contributed to CFIF, it is not surprising that most people contributed money. The committee primarily requested money, through personal and public communication channels. Even though most people ( $80.5 \%$ in the selected sample) contributed money, this case is not an example of crowdfunding where people micro-finance initiatives. Firstly, the contributions received were certainly more than money and included materials, 
knowledge and volunteers. Secondly, the correspondence also highlights that money was not the only valuable contribution. In fact, people wanted to contribute in more personal ways. Some of those who could not help financially wrote an article about Florence and the flood. This, in turn, would have raised awareness and motivated people to contribute.

The role of volunteers in the aftermath of the 1966 flood has been widely discussed. The volunteers are popularly referred to as Mud Angles [57, [58]. Waters 9] mentioned that students worked in removing the books from the affected area by forming human chains. Ted Kennedy [59] appreciated the work of Italian students. However, volunteering was not limited to students and Italians only. The correspondence suggests international individuals volunteered as experts and non-experts. People's willingness to volunteer in Florence at their own expense highlights their attachment to the cultural heritage of the city. It also suggests that cultural heritage can be valuable to people beyond a country's national boundaries.

Current research on crowdsourcing elaborately discusses the motivation to participate, particularly focusing on why people volunteer or contribute. Understanding volunteer's motivation is important for retaining them 60. Starbird et al. mention that these reasons are complex and context-dependent 61]. In this paper, I analyzed how the crowd was motivated. This understanding will help in defining rules of engagement that can be useful for crowdsourcing initiatives. Four main factors were found to be motivating people to contribute: 1) the call to participate, 2) the media, 3)influencers, and 4) a strong personal memory of the city. Memory was found to be the greatest motivating factor, followed by the call to participate, media and influencers. However, it is difficult to assess the true degree of influence of the motivating factors. Firstly, Table 5 illustrates that the motivating factors were close in numbers. Secondly, multiple factors were also found to be motivating a few sources. Moreover, the degree of influence of the motivating factors may differ in the whole dataset. Therefore, these findings cannot be generalized.

As we saw in section 4.3 , the call to participate was elaborate, extensive and 
gave a sense of urgency. The analysis demonstrate the importance of utilizing the existing network of potential contributors. Moreover, it also highlights the importance of utilizing public communication channels to disseminate the initiative. It can be concluded from the analysis that the more rigorous a call is, the more likely it is to attract participants in a crowdsourcing initiative.

The analysis revealed that the news media played a crucial role in organizing the response after the flood. This highlights the importance of mainstream media organizations during disasters. Starbird \& Palen 62 and Bruns et al. [63] found that users tend to circulate messages from established media organizations. Lascarides \& Vershbow [43] report attention spikes from the public upon significant new press or social media coverage. The news media can play a vital role in disseminating news and gaining participants in crowdsourcing initiatives. Hence, the need to build a community around the media between crises, as suggested by Castillo [60].

The analysis revealed that some of the sources were influential people in society. The role of prominent politicians, activists and professors in the context of the 1966 flood has been documented and widely discussed. Prominent figures René Maheu (the Director-General of UNESCO), Ted Kennedy, Jacqueline Kennedy and Liz Taylor appealed to the public to contribute. The role of influencers is mirrored in today's context as well. Starbird \& Palen [62 and Sutton et al. 64] found that messages from Twitter accounts with many followers are circulated more. The analysis also suggests that an influencer need not be a prominent figure in society but also can be a teacher, parent, friend or colleague. This highlights the importance of "the crowd" in motivating others. In other words, the crowd also performs the call to participate, thereby creating motivation in their network.

The analysis has a few limitations. The selected sample is limited, representing only about $24 \%$ of the correspondence. There is over-representation of language and location in the available dataset, in that the majority of correspondence $(64 \%)$ is in Italian and sent from Italy. As a result, the selected sample also has over-representation of language and location. The dataset contains 
mostly correspondence sent from sources, and little correspondence sent from CFIF is available. Lastly, the analysis presented in this paper refers only to the work of the CFIF and does not include the committees in other countries.

\section{Conclusion}

This research addressed two questions: How did the people respond to the cultural heritage damaged during the 1966 Florence Flood? And, moreover, how were they motivated to do so? A total of 180 out of 753 correspondence sources were selected for analysis, using random sampling. The selected sample is diverse, and includes correspondence from Italians and internationals; and public and private bodies; as well as a combination of telegrams, typed letters and handwritten letters. Three main themes emerged from the manual content analysis of the correspondence- action, memory and sentiment. In letters, the three themes were found to be closely related, particularly in internationals' responses. On the other hand, telegrams were short and focused only on action. The committee received contributions in the form of money, materials, volunteers and knowledge from two distinct categories: experts in conservation and restoration, and non-experts. The most popular contribution was money. Four main factors were found to be motivating people to contribute: 1) the call to participate, 2) media, 3) influencers, and 4) memory of the city. Memory was the greatest motivating factor, followed by the call to participate, media and influencers.

Overall, this initiative is particularly relevant in today's context where the frequency and severity of disasters affecting cultural heritage have increased tremendously [10. In particular, it emphasizes how to initiate a crowdsourcing campaign to restore cultural heritage; who will contribute, or who is most likely to contribute; and, finally, how to motivate people to contribute. Further work includes analysis of all 753 sources of correspondence. The scope of work can also be extended to use archival material such as the Arthur T. Hamlin papers at the Columbia University, Borsook Eve. Papers and CRIA archives at the 
Villa I Tatti, The Harvard University Center for Italian Renaissance Studies, to understand the response in depth. Archives of newspapers and magazines from across the world can also be referred to in conducting further research. This case can also be compared with case studies from present times in order to compare and contrast the findings of this study.

\section{Appendix A.}

This section provides a few examples of correspondence. Some of these correspondence items have been translated to English. Also, the spelling or grammatical mistakes in these letters have been kept as is, to maintain the authenticity of the correspondence. Lastly, the personal details (e.g the name of correspondent and location) have been removed where necessary. The aim is to provide an overview of the data used for analysis and support the results described in section 4. instead of highlighting who contributed what or how much.

1. I read Newyork Times your name glad that initiative is in your hands I offer ten thousand dollars that I send as soon as established American committee greetings to you and Licia 8

2. I am glad to contribute to an international fund for the resurrection of Florence- I am sad it is necessary. In 1964 through the eyes of Dr Anne Marie Baldoni my guide, I learned to love Florence, which is very easy. Please accept this small token. I am an artist, but I make more money in my shoe store- Place this check where it will do the most good. She will remember me as the man who sketched everything in sight 9

3. We have heard that you are collecting contribution to help save the heritage to Florence. While my friend and I have no money, we wonder if there is

\footnotetext{
${ }^{8}$ Alluvione di Firenze 1966 - Comitato Fondo Internazionale per Firenze, Box 2, Fondazione Centro Studi SullArte Licia e Carlo Ludovico Ragghianti, Lucca Italy.

${ }^{9}$ Alluvione di Firenze 1966 - Comitato Fondo Internazionale per Firenze, Box 6, Fondazione Centro Studi SullArte Licia e Carlo Ludovico Ragghianti, Lucca Italy.
} 
any program whereby we could come to Florence (in perhaps June) to help in any way. We would be able to pay our fares there and back if only there were a family or someplace to stay. We are both art students and would be honored to be of service to you. If you know of any such programs please advise us 10

4. The great loss which Firenze suffered in the recent floods has touched the heart of a great many Americans. thousands like myself have at one time or another come to worship humbly that wonderful and ancient city from which so much glorious Italian art has drawn its inspiration. When news came of the damages to some of those priceless works of art, we literally wept, as the Florentines must have wept. For we had seen and revered them, had stored up unforgettable memories of their magnificence. My offering is small, but it comes from a full heart. I know some of the treasures are beyond saving, but there is much work that can and must be dome to restore the others. I want to feel I am a part of that work, and of that city. For in a sense, Firenze is the spiritual home of everyone who loves and admires the finest art in Italy's glorious cultural civilization. 11

5. PLEASE ACCEPT THE ENCLOSED CHECK AS A TOKEN OF MY AND MY WIFE'S ESTEEM FOR THE GREAT CITY OF FLORENCE IN THIS TRAGIC HOUR 12

6. In answer your cable am sending immediate donation from Thos Agnew and Sons 43 Oldbondstreet London to British Italian Society With deepest Sympathy. 13

7. Just a little help out in the emergency in the memory of two short visits

\footnotetext{
${ }^{10}$ Alluvione di Firenze 1966 - Comitato Fondo Internazionale per Firenze, Box 7, Fondazione Centro Studi SullArte Licia e Carlo Ludovico Ragghianti, Lucca Italy.

${ }^{11}$ Alluvione di Firenze 1966 - Comitato Fondo Internazionale per Firenze, Box 5, Fondazione Centro Studi SullArte Licia e Carlo Ludovico Ragghianti, Lucca Italy.

${ }^{12}$ Alluvione di Firenze 1966 - Comitato Fondo Internazionale per Firenze, Box 3, Fondazione Centro Studi SullArte Licia e Carlo Ludovico Ragghianti, Lucca Italy.

${ }^{13}$ Alluvione di Firenze 1966 - Comitato Fondo Internazionale per Firenze, Box 2, Fondazione Centro Studi SullArte Licia e Carlo Ludovico Ragghianti, Lucca Italy.
} 
in Florence. Address given in New York Times ${ }^{14}$

8. As successor to comfort director National Gallery of Canada Have presented brief to secretary of state offering cooperation national Gallery STOP and asking for financial support for situation in Italy Jean Boggs Director NaGalCan 15

9. I have your cable and hasten to reply that we are working through the Committee to Rescue Italian Art as organised in the United States under the Honorary Chairmanships of Mrs. John F. Kennedy and Mr. Lehman. All funds raised will be transmitted through this Committee, Rest assured that our sympathies are with you and that we will do everything we can to assist 16

10. Dear friend, I am sending you here one of my articles on the wave in Florence. Unfortunately, Jevil's financial situation is bad. I hope, my friends, that you have a friend 17

11. RESTORATION OF FLOOD-DAMAGED ART in Florence, Italy, is the goal of a drive to raise $\$ 3.2$ million by a national committee which has $U W$ representatives on Milwaukee and Madison campuses. Kack Wasserman (UWM-Chm Art Hist) was invited to head the campaign in Wisconsin. He said the donation may be sent to him or to the Committee to Rescue Italian Art, Post Office Box 1414, Providence, R.I Meantime, in Madison Olga S. Zingale (Ext) and a community committee said it will forward to the national office the donations sent to the Madison Fund for the Restoration of Art in Florence, Post Office Box 521 18

\footnotetext{
${ }^{14}$ Alluvione di Firenze 1966 - Comitato Fondo Internazionale per Firenze, Box 3, Fondazione Centro Studi SullArte Licia e Carlo Ludovico Ragghianti, Lucca Italy.

${ }^{15}$ Alluvione di Firenze 1966 - Comitato Fondo Internazionale per Firenze, Box 9, Fondazione Centro Studi SullArte Licia e Carlo Ludovico Ragghianti, Lucca Italy.

${ }^{16}$ Alluvione di Firenze 1966 - Comitato Fondo Internazionale per Firenze, Box 4, Fondazione Centro Studi SullArte Licia e Carlo Ludovico Ragghianti, Lucca Italy.

${ }^{17}$ Alluvione di Firenze 1966 - Comitato Fondo Internazionale per Firenze, Box 3, Fondazione Centro Studi SullArte Licia e Carlo Ludovico Ragghianti, Lucca Italy.

${ }^{18}$ Alluvione di Firenze 1966 - Comitato Fondo Internazionale per Firenze, Box 12, Fon-
} 
12. I am enclosing with this letter a bank draft for $\$ 65.00$ U.S. to add to the fund which I understand you are heading, for the restoration and repair of the art treasures of Florence. This money represents an informal collection to which most of the members of my company have contributed. Many of us have visited Florence, and many more who contributed have not had the opportunity, but we all feel the urgency of your work demands our reply in this manner. I only regret the sum is not larger 19

13. A bad grippe and further consequences prevented me to write them down first and then start to take action to help remedy the damage suffered by flooding in Florence. Unfortunately, having passed news of his wishes to the other comrades, I was informed about some facts addressed to the help of the Florentines during these days of disaster. Mrs. Margarita in Ken, from our section, gave a lecture on Florence to the Mexican Architects Society. The entry ticket cost 100 Pesos, both Lire 20,000. About 1,100,000 have gathered. We have contributed with the price of 10 tickets. Between this conference and an evening of cinema organized by the Embassy of Italy, 12,000,000 were sent to the Italian government. Where other contributions were compressed. In these days a Mexican Help Committee has been set up in Florence, where our Association forms part. A large number of painters, engravers and sculptors have donated works that will be auctioned soon. We hope that the economic results are good. I'll let you know, of course 20

14. The Circolo di cultura di Locarno, which I have the honor to chair, wants to give its modest contribution to those under your guidance who are engaged in the recovery of many works of art and documents of our common civilization offended by the recent flood in Florence. In the next few days

\footnotetext{
dazione Centro Studi SullArte Licia e Carlo Ludovico Ragghianti, Lucca Italy.

${ }^{19}$ Alluvione di Firenze 1966 - Comitato Fondo Internazionale per Firenze, Box 5, Fondazione Centro Studi SullArte Licia e Carlo Ludovico Ragghianti, Lucca Italy.

${ }^{20}$ Alluvione di Firenze 1966 - Comitato Fondo Internazionale per Firenze, Box 2, Fondazione Centro Studi SullArte Licia e Carlo Ludovico Ragghianti, Lucca Italy.
} 
our cashier will send you the sum of 536 Swiss francs collected at our last meeting. I am also pleased to inform you that the students of the Scuola Magistrale cantonale di Locarno, in which I teach, have organized for the restoration of the works of art of Florence, a public lottery subscription for which many Ticino artists or residents of the Ticino have put available paintings, sculptures, drawings. We hope that this action, extended to the whole of Ticino, will succeed and can make a valid contribution; it will end in mid-January. After 20 January, on a day that has not yet been fixed, the prize draw will take place. On that occasion, your commitments would allow you to be our most welcome guest and to hold a conference on a topic that you may want to propose? I make this proposal on behalf of the Director of the Scuola Magistrale who is also mayor of the city 21

15. At the initiative of the Direction of the Civic Museum of Pistoia, in the next month of December, a large exhibition-sale of works by Italian and foreign artists will be inaugurated in the Ghibelline Room of the Museum. The proceeds of which will be used as a contribution for the restoration of works of art of Florentine museums and art galleries affected by the floods. The initiative, promoted by the Director of the Museum and by a group of Italian and foreign artists, is being flocked by Italy and abroad by artists of all tendencies, all united in the noble intent to contribute to the rescue of deteriorated works of art. They will unite their efforts to contribute with their works to build a solidarity fund that will be able to see Italian and foreign artists in the common intent of bringing help to Italy for the conservation of its works of art. The works offered for sale will be presented by a catalog published by the municipality of Pistoia to which Italian critics will collaborate 22

\footnotetext{
${ }^{21}$ Alluvione di Firenze 1966 - Comitato Fondo Internazionale per Firenze, Box 4, Fondazione Centro Studi SullArte Licia e Carlo Ludovico Ragghianti, Lucca Italy.

${ }^{22}$ Alluvione di Firenze 1966 - Comitato Fondo Internazionale per Firenze, Box 9, Fondazione Centro Studi SullArte Licia e Carlo Ludovico Ragghianti, Lucca Italy.
} 
16. I hope this suggestion is of some use to you in rescuing the books damaged in the recent floods. HOW TO DRY BOOKS. Use electric fans, preferably oscillating fans. Lay the books down in front of the fan, open edge toward the fan. Some books dry better standing up. Don't put books too close to fan, or the wind may tear the wet paper. While the books are drying, an attendant should move among them. peeling the pages apart gently, so that wet pages do not dry stuck together. When they are partially dry, the pages of each book can be thumbod occasionally to admit dry air. One fan can treat 5-10 books at a time. One person can attend to quite a few fans and books. Dryers using warmed air might be worth trying on some books, but I haven't tried it. I have used the method described above, to salvage several hundred books that were badly soaked, with excellent results, not one stuck page. Deepest sympathy and best wishes ${ }^{23}$

17. The enclosed letters are from eight and nine year old children. Our project to help was the result of class discussions of current events. It was their own idea to do something to earn money to send to Florence. Though this isn't a large amount, it is sent with sincere concern and desire to help. Our class bulliten board has been crowded with articles and pictures of the flood. These children are genuinely concerned and want to help. I was in Italy during the summer of 1965 and it was a highlight of my life. My particular interest in opera and my feelings at having of 14 feet of mud in the opera house were greatly upset. I'm sure though that the Italian spirit will prevail and repair will quickly be made. I am planning to visit Florence again during the summer of 1967 and even the flood will not change these plans.

Best wishes to you in your monumental task of repair and restoration.

I am very sad about the Floods. Our class has made $40 \$$ in a cookie and

\footnotetext{
${ }^{23}$ Alluvione di Firenze 1966 - Comitato Fondo Internazionale per Firenze, Box 6, Fondazione Centro Studi SullArte Licia e Carlo Ludovico Ragghianti, Lucca Italy.
} 
candy sale. I know it is needed very much, and will be in good use. I hope you can fix the houses and the operas and beautiful pantings (sic).

This is money we made. I hope it will help your friends and our to get to safety soon. How are things doing? I can answer that, NOT TOO GOOD! Get in shape soon.

We are sorry that the flood has ruined everything. That is why we are sending money to you. It's about \$40. We will help Italy in anyway we can. We do hope you and Italy get better.

Love

P.s IS POPE HURT and is the VATICAN?

good-by (sic) for now ${ }^{24}$

18. Your circular letter addressed to the President of the Noble Foundation has been forwarded by Dr. Anders Osterling, chairman of the Nobel Committee for Literature, to us for attention. The catastrophe which recently has come to Italy and endangered many of the irreplaceable treasures common to our Western civilization has caused a spontaneous will to help, also in Sweden. The task of the Nobel Foundation, however, is limited by the testament of Alfred Nobel to prize-awarding activities. We therefore regret that our funds cannot be used for the urgent and worthy caused mentioned in your letter 25

19. In the name of my fellow Professors Kenneth Evett, Maurice Neufeld, Pietro Pucci and Robert Wilson, I enclose a check for \$1100 collected from the students and the Cornell University academic body for your International Fund for Florence. We know of your competence, your great

\footnotetext{
${ }^{24}$ Alluvione di Firenze 1966 - Comitato Fondo Internazionale per Firenze, Box 3, Fondazione Centro Studi SullArte Licia e Carlo Ludovico Ragghianti, Lucca Italy.

${ }^{25}$ Alluvione di Firenze 1966 - Comitato Fondo Internazionale per Firenze, Box 9, Fondazione Centro Studi SullArte Licia e Carlo Ludovico Ragghianti, Lucca Italy.
} 
love for Florence, your probity, and we therefore thought that you are the best person to use our little help in the best and most effective way, without delay and bureaucratic formalities. We hope to send you another small sum in January, and we wish you the best wishes for the rebirth of Florence 26

20. The professor. Guy Tosi informs me that he heard the Syndacat National des Editeurs franais, which would be willing to ask its members to participate in the replacement of French books in the damaged libraries of Florence. Naturally, it would be to provide all or part of the current works of each publisher. You should let me have, in the shortest possible time, lists in three copies, to be sent to prof. Tosi, who would then carry out the practice at the syndicated publishers. Naturally, I do not know which entity will have this gift, but I think it would still be useful for university libraries. To this end, you should have the courtesy to ask the library managers themselves to fill in the lists indicated, divided by publishers and related works requested by them. with the most cordial thanks and greetings 27

21. I have read in our newspaper of your most courageous and honorable work in the restoration of Florence, and would like to offer my personal services to assist in any way. I am a student of Brooklyn College, a division of New York University and plan to take a trip of Italy this summer. I have been looking forward to visiting your historic city for a long time. I am 21 years old and will be graduating from college in June. Please reply to me as soon as possible so that my friend, Edward Potter, and myself can make our summer plans accordingly. It is not very often that history can record such an admirable effort by the people of Florence. Much respect is

\footnotetext{
${ }^{26}$ Alluvione di Firenze 1966 - Comitato Fondo Internazionale per Firenze, Box 3, Fondazione Centro Studi SullArte Licia e Carlo Ludovico Ragghianti, Lucca Italy.

${ }^{27}$ Alluvione di Firenze 1966 - Comitato Fondo Internazionale per Firenze, Box 2, Fondazione Centro Studi SullArte Licia e Carlo Ludovico Ragghianti, Lucca Italy.
} 
due you and other Florentines for your dedication. Florence has been one of the cultural centers of the world in the past, and I am confident she will remain so. Thank you for your cooperation 28

22. I have been very moved by the accounts in the newspapers of the terrible artisitic and cultural losses in your city. Please accpet the enclosed small contribution to help you in the work of restoring and repairing which lies ahead of you. All best wishes 29

23. Enclosed please find a small contribution toward the recovery of the art of Florence. The pictures of the tragedy have made us heartsick. Wish I could be there to help my hands to restore some of the beauty of the most beautiful city in the world. Hope some way will be found that we, over here will be able to help in more personal ways than contributing money. 30

24. The Evening Post of Wellington, New Zealand reported on 30/11/1966 The floods of the last few weeks have been the worst in the history of Florence with water rising far higher than the previous worst flood in 1277. Disaster has overwhelmed the procurators of art galleries, museums, churches, and libraries in Florence, to say nothing of the population. Huge sums of money will be required, and already the Italian Government has suspended various operations to divert funds to saving this enormous collection of masterpieces. As additional funds are urgently required, donations no matter how small will be gratefully received by ... 31

\footnotetext{
${ }^{28}$ Alluvione di Firenze 1966 - Comitato Fondo Internazionale per Firenze, Box 2, Fondazione Centro Studi SullArte Licia e Carlo Ludovico Ragghianti, Lucca Italy.

${ }^{29}$ Alluvione di Firenze 1966 - Comitato Fondo Internazionale per Firenze, Box 2, Fondazione Centro Studi SullArte Licia e Carlo Ludovico Ragghianti, Lucca Italy.

${ }^{30}$ Alluvione di Firenze 1966 - Comitato Fondo Internazionale per Firenze, Box 3, Fondazione Centro Studi SullArte Licia e Carlo Ludovico Ragghianti, Lucca Italy.

${ }^{31}$ Alluvione di Firenze 1966 - Comitato Fondo Internazionale per Firenze, Box 4, Fondazione Centro Studi SullArte Licia e Carlo Ludovico Ragghianti, Lucca Italy.
} 


\section{Appendix B. Data Availability}

Datasets related to this article can be found was uploaded on Mendeley and can be found using this link.

\section{References}

[1] D. Geiger, M. Rosemann, E. Fielt, M. Schader, Crowdsourcing information systems - definition, typology, and design, Proceedings of the 33rd International Conference on Information Systems. 2012. Association for Information Systems/AIS Electronic Library (AISeL). (2012) 1-11.

[2] D. C. Brabham, Crowdsourcing as a model for problem solving: An introduction and cases, Convergence 14 (1) (2008) 75-90.

[3] E. Estellés-Arolas, F. González-Ladrón-de-Guevara, Towards an integrated crowdsourcing definition, Journal of Information Science 38 (2) (2012) 189 200.

[4] S. Ellis, A history of collaboration, a future in crowdsourcing: positive impacts of cooperation on british librarianship, Libri 64 (1) (2014) 1-10.

[5] J. Howe, The rise of crowdsourcing, Wired magazine 14 (6) (2006) 1-4.

[6] Nd, Editorial: Thorough flood, The Burlington Magazine 128 (1004) (1986) 779 .

[7] UNESCO, Florence, Venice: UNESCO opens world campaign, 1967, available from https://unesdoc.unesco.org/ark:/48223/pf0000078222 Accessed on: 2 September 2019.

[8] W. J. Young, The florentine flood, november4, 1965, Boston Museum Bulletin 66 (345) (1968) 101-115.

[9] S. Waters, Waters Rising: Letters from Florence, Legacy Press, Ann Arbor, 2016. 
[10] J. Taboroff, Natural disasters and urban cultural heritage: A reassessment, Building Safer Cities (2003) 233-240.

[11] P. Giovanni, Le belle arti a firenze sotto il diluvio, Paragone. Arte 18 (203) (1967) 41-56.

[12] P. Emanuele, Storico Dellarte E Uomo Politico, Profilo biografico di Carlo Ludovico Ragghianti, Edizioni ETS, 2018.

[13] K. K. Taylor, Diary of Florence in Flood, New York: Simon and Schuster, 1967.

[14] R. Clark, Dark Water: Flood and Redemption in Florence-The City of Masterpieces, Anchor, 2008.

[15] D. Barrett, S. Kraczyna, The Great Flood of Florence, 1966: A Photographic Essay, Vol. 1, Syracuse University Press, 2007.

[16] E. Pucci, T. Paterson, The Flood in Florence, SBonechi Editore, 1966.

[17] S. Messeri, S. Pintus, 4 Novembre 1966 L'alluvione a Firenze, Ibiskos Editrice Risolo, 2006.

[18] D. Alexander, The florence floodswhat the papers said, Environmental Management 4 (1) (1980) 27-34.

[19] K. M. J. Phillips, Archaeological flood damage, American Journal of Archeology 71 (1) (1967) 113-114.

[20] M. Picker, Letter from martin picker, Journal of the American Musicological Society 20 (1) (1967) 147-150.

[21] A. Hamlin T., The libraries of florence november 1966, ALA Bulletin 61 (2) (1967) 141-151.

[22] M. L. R. Bonelli, Rehabilitation of the istituto e museo di storia della scienza in florence, Technology and Culture 10 (1) (1969) 62-64. 
[23] N. S. Brommelle, The restoration of damaged art treasures in florence and venice, Journal of the Royal Society of Arts 118 (5165) (1970) 260-269.

[24] P. Conway, M. Conway, Flood in florence, 1966: A fifty-year retrospective, Michigan Publishing, 2016.

[25] J. Hogg, Dear Eddie and Popp; Letters from the Florence Flood of '66, Studio Art Centers International Florence, The Underdog Press, 2010.

[26] S. B. Liu, Crisis crowdsourcing framework: Designing strategic configurations of crowdsourcing for the emergency management domain, Computer Supported Cooperative Work (CSCW) 23 (4-6) (2014) 389-443.

[27] M. Poblet, E. García-Cuesta, P. Casanovas, Crowdsourcing tools for disaster management: A review of platforms and methods, in: International Workshop on AI Approaches to the Complexity of Legal Systems, Springer, 2013, pp. 261-274.

[28] C. Ernst, A. Mladenow, C. Strauss, Collaboration and crowdsourcing in emergency management, International Journal of Pervasive Computing and Communications 13 (2) (2017) 176-193.

[29] H. Gao, X. Wang, G. Barbier, H. Liu, Promoting coordination for disaster relief-from crowdsourcing to coordination, in: International Conference on Social Computing, Behavioral-Cultural Modeling, and Prediction, Springer, 2011, pp. 197-204.

[30] N. Kankanamge, T. Yigitcanlar, A. Goonetilleke, M. Kamruzzaman, Can volunteer crowdsourcing reduce disaster risk? a systematic review of the literature, International Journal of Disaster Risk Reduction (2019) 101097.

[31] P. Meier, Digital humanitarians: how big data is changing the face of humanitarian response, Crc Press, 2015.

[32] A. R. Shahid, A. Elbanna, The impact of crowdsourcing on organisational practices: The case of crowdmapping, in: ECIS 2015 Completed Research Papers. Paper 166, 2015. 
[33] S. Koswatte, K. McDougall, X. Liu, Sdi and crowdsourced spatial information management automation for disaster management, Survey Review 47 (344) (2015) 307-315.

[34] T. Radford, Nepal earthquake: A note of thanks to hots aerial imagery providers, available from https://www.hotosm.org/updates/ 2015-07-14_nepal_earthquake_a_note_of_thanks_to_hot\%E2\%80\% 99s_aerial_imagery_providers Accessed on: 2 September 2019.

[35] L. Palen, R. Soden, T. J. Anderson, M. Barrenechea, Success \& scale in a data-producing organization: The socio-technical evolution of openstreetmap in response to humanitarian events, in: Proceedings of the 33rd annual ACM conference on human factors in computing systems, ACM, 2015, pp. 4113-4122.

[36] N. Prutzer, The mapping crowd: Macrotask crowdsourcing in disaster response, in: Macrotask Crowdsourcing, Springer, 2019, pp. 253-275.

[37] D. Yang, D. Zhang, K. Frank, P. Robertson, E. Jennings, M. Roddy, M. Lichtenstern, Providing real-time assistance in disaster relief by leveraging crowdsourcing power, Personal and Ubiquitous Computing 18 (8) (2014) 2025-2034.

[38] M. Imran, C. Castillo, J. Lucas, P. Meier, S. Vieweg, Aidr: Artificial intelligence for disaster response, in: Proceedings of the 23rd International Conference on World Wide Web, ACM, 2014, pp. 159-162.

[39] W.-Y. Lin, T.-H. Wu, M.-H. Tsai, W.-C. Hsu, Y.-T. Chou, S.-C. Kang, Filtering disaster responses using crowdsourcing, Automation in Construction 91 (2018) 182-192.

[40] A. Tandon, Post-disaster damage assessment of cultural heritage: Are we prepared?, in: ICOM-CC 18th Triennial Conference, 2017.

[41] J. A. Peschanski, After a catastrophic fire at the national museum of brazil, a drive to preserve what knowledge remains, 
available from https://wikimediafoundation.org/news/2018/09/10/ national-museum-brazil-fire/ Accessed on: 2 September 2019.

[42] J. Oomen, L. Aroyo, Crowdsourcing in the cultural heritage domain: opportunities and challenges, in: Proceedings of the 5th International Conference on Communities and Technologies, ACM, 2011, pp. 138-149.

[43] M. Lascarides, B. Vershbow, Whats on the menu?: Crowdsourcing at the new york public library, Crowdsourcing Our Cultural Heritage (2014) 1131137.

[44] T. Causer, M. Terras, many hands make light work. many hands together make merry work: Transcribe bentham and crowdsourcing manuscript collections, Crowdsourcing Our Cultural Heritage (2014) 57-88.

[45] M.-L. Ayres, Singing for their supper: Trove, australian newspapers, and the crowd, in: IFLA WLIC 2013 - Singapore - Future Libraries: Infinite Possibilities, 2013.

[46] P. Nourse N, Insole, J. Warren, Having a lovely time: localized crowdsourcing to create 1930s street view of bristol from a digitized postcard collection, in: H. Roued-Cunliffe, A. Copeland (Eds.), Participatory heritage, Facet Publishing, 2017.

[47] L. of Congress. Prints, P. Division, M. Springer, B. Dulabahn, P. Michel, B. Natanson, D. W. Reser, N. B. Ellison, H. Zinkham, D. Woodward, For the common good: The library of congress flickr pilot project, Library of Congress, Prints and Photographs Division, 2008.

[48] Online database of photos reflect on 9/11 aftermath, available from https://www.911memorial.org/blog/ online-database-photos-reflect-911-aftermath Accessed on: 12 January 2016.

[49] S. Bernstein, Crowdsourcing in brooklyn, in: Crowdsourcing our Cultural Heritage, Routledge, 2016, pp. 39-65. 
[50] P. Summerfield, Mass-observation: social research or social movement?, Journal of Contemporary History 20 (3) (1985) 439-452.

[51] T. Owens, Digital cultural heritage and the crowd, Curator: The Museum Journal 56 (1) (2013) 121-130.

[52] S. Winchester, The Professor and the Madman: A Tale of Murder, Insanity and the Making of the Oxford English Dictionary, Harper Perennial, 1998.

[53] K. Starbird, What "crowdsourcing" obscures: Exposing the dynamics of connected crowd work during disaster, arXiv preprint arXiv:1204.3342.

[54] K. Krippendorff, Content analysis: An introduction to its methodology, Sage publications, 2018.

[55] R. P. Weber, Computer-aided content analysis: A short primer, Qualitative sociology 7 (1-2) (1984) 126-147.

[56] J. Surowiecki, The wisdom of crowds, Anchor, 2005.

[57] D. Erasmo, Angeli del fango. La meglio giovent nella Firenze dell'alluvione, Giunti Editore, 2006.

[58] D. Erasmo, Angeli del fango. La meglio giovent nella Firenze dell'alluvione a 50 anni di distanza, Giunti Editore, 2016.

[59] V. I. Tatti, Ted kennedy cria appeal, available from https://cria. itatti.harvard.edu/ Accessed on: 22 May 2019.

[60] C. Castillo, Big crisis data: Social media in disasters and time-critical situations, Cambridge University Press, 2016.

[61] K. Starbird, G. Muzny, L. Palen, Learning from the crowd: collaborative filtering techniques for identifying on-the-ground twitterers during mass disruptions, in: Proceedings of 9th International Conference on Information Systems for Crisis Response and Management, ISCRAM, 2012, pp. 1-10. 
[62] K. Starbird, L. Palen, Pass it on?: Retweeting in mass emergency, in: Proceedings of 7th International Conference on Information Systems for Crisis Response and Management, ISCRAM, 2010.

[63] A. Bruns, J. E. Burgess, K. Crawford, F. Shaw, \# qldfloods and@ qpsmedia: Crisis communication on twitter in the 2011 south east queensland floods.

[64] J. Sutton, E. S. Spiro, B. Johnson, S. Fitzhugh, B. Gibson, C. T. Butts, Warning tweets: Serial transmission of messages during the warning phase of a disaster event, Information, Communication \& Society 17 (6) (2014) 765-787. 